ELORE (ISSN 1456-3010), vol. $14-1 / 2007$.

Julkaisija: Suomen Kansantietouden Tutkijain Seura ry.

[http://www.elore.fi/arkisto/1_07/wec_b_1_07.pdf]

\title{
KIRJA-ARVIO: \\ PORSTUAN KAUTTA KEITTÖÖN, EHKÄ JOPA OLOHUONEESEEN
}

Agren, Marja 2006: "Du är finsk, eller...?". En etnologisk studie om att växa upp och leva med finsk bakgrund i Sverige. Göteborg: Arkipelag. 297 sivua.

\section{$\underline{\text { Lotta Weckström }}$}

Etnologi Marja Ågrenin väitöskirja on kuvaus 14 göteborgilaisen suomalaistaustaisen nuoren aikuisen mielikuvista suomalaistaustan moninaisista merkityksistä Ruotsissa. Ågrenin tutkimus on toteutettu osana suomalais-ruotsalaista tutkimusprojektia "Kahden puolen Pohjanlahtea - Svenskt i Finland, finskt i Sverige", jossa Suomen Sallasta Ruotsiin suuntautunut muuttoliike luo pohjaa Ågreninkin työlle. Tutkijan mukaan väitöskirjan keskeinen tehtävä on analysoida ja kuvata suomalaisen perhetaustan merkityksiä haastateltavien arjessa ja heidän paikalleen yhteiskunnassa sekä pohtia ryhmään kuulumisen kokemusta.

Alku on, ehkä tarkoituksellisesti, rikkonainen, mutta jatkossa teksti muuttuu yhtenäisemmin eteneväksi ja tarjoaa mielenkiintoisen lukukokemuksen. Teksti on sujuvaa: teoria-empiria-analyysi-päätelmät -rakenteen rikkominen toimii hyvin. Teoria ja empiria, haastattelupätkät ja tutkijan ääni punoutuvat kudelmaksi, jota lukiessa ei jää epäselväksi, että kirjoittaja on kotonaan etnologian alalla ja hyvin perehtynyt tutkimaansa aiheeseen. Ågren kirjoittaa erittäin hyvin. Kieli on rehevää ja assosioivaa. Harvaa väitöskirjaa tekee oikeasti mieli lukea kannesta kanteen, tätä sen sijaan on vaikea jättää kesken.

\section{ONGELMAKESKEINEN TUTKIMUSTRADITIO JA SOSIAALISEN LUOKAN MERKITYS}

Ågren nostaa keskeiseksi teemaksi potentiaalisen ongelmakeskeisyyden, joka tutkijan mukaan värittää suomalaisuudentutkimuksen kenttää ja mediaa niin Ruotsissa kuin Suomessakin. Suomalaistaustaisuus Ruotsissa liitetään helposti yhteiskunnallisiin ja 
henkilötason ongelmiin. Tämä on väitöskirjan kantava teema, johon Ågren palaa purkaen ajatusta useaan otteeseen. Tutkija arvelee, että tarve löytää suomalaistaustaisten henkilöiden elämästä ahdistavia muistoja, kurjuutta ja toisenlaisuuden kipeitä kokemuksia johtunee ennakkoasenteesta, jossa suomalaisuus kytkeytyy ongelmiin. Ågren tuulettaa ongelmakeskeisyyden ulos suomalaisuudentutkimuksesta, antaen haastateltaviensa kertoa tarinoitaan Göteborgissa kasvamisen kontekstissa eikä niinkään suomalaisperheessä kasvamisen kontekstissa.

Toiseksi keskeiseksi teemaksi Ågren on ottanut suomalaisuuden luokkasidonnaisuuden kokemuksen Göteborgissa. Hän pohtiikin luokan käsitettä ja kokemusta mielenkiintoisesti ja laajapohjaisesti. Mitä valtiovalta tarkoittaa sopeutumisella, entä mitä "sopeutujat" itse ajattelevat asiasta? Millaisia merkityksiä haastateltavat antavat työläistaustalleen ja suomalaisuudelle sopeutumisen kontekstissa? Onko suomalainen yhtä kuin duunari? Ågren käyttää osuvaa "porstuan kautta keittiöön" -metaforaa pohdiskellessaan integraation käsitettä ruotsalaisessa yhteiskunnassa. Melkein kuka tahansa voi astua eteiseen, siihen tilaan ruotsalaisessa yhteiskunnassa, joka symboloi avointen ovien politiikkaa. Keittiöön, integraation välihuoneeseen, jossa arkeen opetteleminen ja integraatio tapahtuvat työn kautta, pääsee osoittamalla ahkeruutta työnteossa. Sen sijaan integraatiota ja hyväksyntää symboloivaa olohuoneen ovea on vaikea saada auki työskentelemättä ensin keittiössä. Mitä "ei-ruotsalaisempi" talossa asuva ja siellä työskentelevä on, sitä vaikeammin olohuoneen ovi avautuu. Ågren onkin samoilla jäljillä Göteborgissa suomalaisia siirtolaismiehiä tutkineen Finnkampen -kirjan (2001) kirjoittajan Jari Kuosmasen kanssa luokan käsitteen liittämisestä etnisten identiteettien analyysiin. Sosiaalinen luokka ja fyysinen olinpaikka näyttävät vaikuttavan voimakkaasti identiteettien muotoutumiseen, tutkijan mielestä joissain tapauksissa jopa voimakkaammin kuin etninen tausta.

\section{KUKA KIRJOITTAA?}

Erityisen merkittävän ja lukemisen arvoisen tästä väitöskirjasta tekee se, että Marja Ågren on ruotsinkielinen ruotsalainen ja yksi harvoista suomalaisia (tai suomalaistaustaisia henkilöitä, kuten poliittisesti korrekti termi Ruotsissa kuuluu) tutkivista, jolla ei ole työn lisäksi mitään henkilökohtaista sidettä suomalaisuuteen tai Suomeen. Hän pohtii avoimesti omaa rooliaan tutkiessaan ja kuvatessaan suomalaistaustaisia henkilöitä Göteborgissa. Ågren korostaa sitä, miten ulkopuolisuus voi olla moninaista ja muuttuvaa, yhtä aikaa ulkopuolisuutta ja sisällä olemista. Tutkijana hän seisoo suomalaisuuden kokemusten ulkopuolella, mutta jakaa kokemuspintaa göteborgilaisuuden, sukupolven kokemuksen ja ruotsalaisuuden alueella. Kirjoittaja kykenee käsittelemään asettamansa kysymykset perusteellisesti ja pohtii kriittisesti myös aihealueita, jotka yleensä jäävät häveliäisyyssyistä vähäiselle tutkiskelulle. Ågren ei kaihda hankaliakaan aiheita vaan tarttuu empimättä niin rasismiin kuin alkoholismiinkin osana analyysiaan. 


\section{LOTTA WECKSTRÖM}

Ågren ei valitettavasti ole liittänyt työtään mihinkään laajempaan, esimerkiksi eurooppalaiseen viitekehykseen, eikä hän pohdi haastateltaviensa ajatuksia muussa kuin göteborgilaisessa mittakaavassa. Valinta saattaa olla tietoinen, mutta kirjoittajan olisi ollut hyvä kertoa tästä lukijalle ja motivoida valintaansa. 14 henkilön haastatteluista voi kertoa useita paikkaansa puolustavia, mielenkiintoisia tarinoita, mutta asetelma olisi antanut hyvät puitteet edes viitata muissa Euroopan maissa tehtyyn tutkimukseen siirtolaisten jälkeläisistä. Sitähän Ågrenin haastateltavat ovat, vaikka haastateltavat ja kirjoittaja termiä välttävätkin. Sidonnaisuus Göteborgiin ja työn "hetkellisyys" tulevat esille myös siinä, että kirjoittaja ei enemmälti käsittele jo tehtyä tutkimusta suomalaisista Ruotsissa. Yksi syy tähän on varmaankin se, ettei kirjoittaja ymmärrä suomea, mutta tutkimusta on toki myös ruotsiksi ja englanniksi. Tutkimuksen jäädessä tavallaan irralleen ajan ja tutkimuksen jatkumosta jää väitöskirja mieleen göteborgilaisuuden tai kaupunki-identiteetin eikä niinkään suomalaistaustaisuuden tutkimuksena. Tämä saattaa olla koko väitöskirjan idea, mutta sen tarkoituksenmukaisuus ei välttämättä välity lukijalle.

Kaiken kaikkiaan Marja Ågren on kirjoittanut hyvän teoksen onnistuen välttämään väitöskirjojen kompastuskiven: miten osoittaa oppineisuutensa lankeamatta päsmäröintiin. Päsmäröinnin sijaan väitöskirja tuulettaa suomalaistutkimuksen kenttää poliittisella sitoutumattomuudella ja virkistävällä keskustelulla suomalaistaustaisuudesta. Kiitosta annan myös tutkijan päätökselle jättää etnologisille tutkimuksille tyypilliset henkilökohtaisen tunnustukselliset kenttätyökokemusten kuvaukset - siis refleksiivisyys, jossa harvoin onnistutaan - pariin varsin lyhyeen kuvaukseen matkasta Sallaan ja osallistumisesta suomalaisten tansseihin Göteborgissa. Ågren liittää kokemuksensa tiiviisti teoreettiseen pohdiskeluun, jolloin ne vievät tekstiä hedelmällisesti eteenpäin.

Väitöskirjan kannet ovat hauska visuaalinen oivallus: etukannen sinikeltainen väritys muuttuu sinivalkoiseksi selän keskellä takakannen värityksen ollessa sinivalkoinen.

\section{KirjallisuUs}

KUOSMANEN, JARI 2001: Finnkampen. En studie av finska mäns liv och sociala karriärer i Sverige. Hedemora: Gidlund.

Filosofian lisensiaatti Lotta Weckström kirjoittaa väitöskirjaa ruotsinsuomalaisista Jyväskylän yliopiston soveltavan kielentutkimuksen keskuksessa. 